\title{
Regeneration status of common woody species in the riparian forests in Southwestern Nigeria
}

\author{
Tolulope Victor Borisade*, Anthony Ifechukwude Odiwe
}

Department of Botany, Obafemi Awolowo University, Ile-Ife, BC220005 Nigeria.

* corresponding author e-mail: tolulopeborisade2017@gmail.com

Received: 23 April 2020 / Accepted: 30 September 2020

\begin{abstract}
Sustainability of woody species in riparian forests requires information on its regeneration status, which is crucial for proper management and conservation of these species but the information is generally lacking in Nigeria. This knowledge of the regeneration status of common woody species in riparian forests guarantees their survival through proper management and conservation. Sampling was done via random method in which five (5) $10 \mathrm{~m} \times 10 \mathrm{~m}$ plots were selected from the study sites giving a total of 45 plots. Therefore, the aim of the study was to assess the structures and status of common woody species in the regeneration layer of riparian forests. There was no significant $(\mathrm{p}>0.05)$ difference in the mean seedling and sapling densities of the common woody species across the riparian forest sites. The regression slope showed on-going regeneration (mostly weak) of the common riparian woody species in all the sites. The regeneration structures indicated reverse J-shaped and have been greatly modified by prevalent anthropogenic activities in the study area. The pattern of regeneration status observed in the seedlings and saplings emergence in the regeneration layer was due to the similar environmental factors that occurred from one site to the other. The intermediate values of tree/shrub ratio shown by the common woody species encountered in the regeneration layer indicated more individuals of shrub size than tree and emphasized the fact that the level of disturbance on-going was moderate across study and possibly that the sites were recovering from disturbances.
\end{abstract}

Keywords: growth, saplings, seedlings, tree/shrub ratio, vegetation.

\section{Introduction}

Riparian zones may be composed of distinctive plant communities not found anywhere else (DSE, 2010), other than where sources of seed or vegetative propagules are present. The exclusion of stock from riparian zones may facilitate the regeneration of trees, shrub and ground layer vegetation leading to increased shading and litter inputs into streams (Robertson \& Rowling, 2000). The regeneration capacity of the riparian vegetation is linked with spatial connectivity (longitudinal, transversal and vertical) dimensionally as guarantor of its continuity in the future/survival (Magdaleno et al., 2010). Regeneration success of riparian woody species can be attributed to intensity of interspecific competition among tree-tree seedlings and tree seedlings- shrubs (Adel et al., 2018). Riparian ecosystems have been found to be dependent on disturbances for the regeneration of some of their vegetation communities (Baker, 2002). The riparian woody vegetation is frequently influenced by floods and occasional wildfires (Pettit \& Naiman, 2007). Oliveira et al. (2014) concluded that identifying the adaptive strategies of plants and their responses to highly selective environmental pressures is pivotal to understand their distribution and ecological needs for survival and regeneration. Sustainability of woody species in riparian forests requires information on its regeneration status, which is crucial for proper management and conservation of these species but are generally lacking in Nigeria. It has been hypothesized that establishment and distribution of species in Nigerian riparian forests is controlled by the interaction 
between fluvial events and ecological requirements of the species that invariably affect their regeneration dynamics. In this part of the world, regeneration of riparian woody species is mainly influenced by flooding rather than fire and anthropogenic activities but there is little documentation on the regeneration structure of riparian forests in $\mathrm{Ni}$ geria. Therefore, the aim of this study was to examine the common woody species that are present in the regeneration layer, their status and structure across the study sites. This study also highlighted the level of anthropogenic activities influencing the regeneration structures and status of dominant woody species across riparian forest sites in Nigeria with Osun State.

The following questions were addressed in this research:

1. What are the common woody species occurring in the regeneration layer of the riparian forests in Southwestern Nigeria?

2. What is the level of anthropogenic disturbance on-going in the regeneration layer and how does it affect the different components (trees, shrubs and saplings) their structures?

\section{Study Area}

The study was carried out in Osun State located in the South-western Nigeria. The state is located within latitude $7.0^{\circ}$ and $9.0^{\circ} \mathrm{N}$ of the equator and longitudes $2.8^{\circ}$ and $6.8^{\circ} \mathrm{E}$. Six local government areas out of thirty in the state were selected for this study.

The local governments were: Ilesha West, Atakumosa West, Ife North, Ife North East, Ife South and Ayedade (Fig 1). These study areas were chosen sequential to the ground-truthing survey carried out between February and April, 2017. Most of the riparian forests within the state were under intense anthropogenic interferences such as deforestation and degradation, mining, farming and fishing activities. Majority of riparian forests were no longer in existence as a result of the anthropogenic interferences/disturbances and urbanization that are occurring at an alarming rate. Some areas, notably in Ife East, were considered sacred; while access was denied in places like Toro and Oku Omonii by the traditional rulers due to their hostility. The study sites were selected based on the fact that they represent areas with minimum anthropogenic disturbance, high plant species diversity and flooding patterns of riparian zones within Osun State. Nine sites were selected within the six local governments namely: Ifetedo, Ibodi, Osu, Famia, Gbongan, Edunabon, Tonkere, Ipetumodu and Ilesha (Fig. 1).

\subsection{Vegetation, Climate and Soils of Osun State}

The vegetation of Osun State had been described as lowland forest zone (Keay, 1959), semi-deciduous moist forests (Charter, 1969) and Guineo-Congolian forest drier type (White, 1983). Hall (1969) also described the vegetation as the dry forest sub-group. The dominant plant families across the riparian sites are Euphorbiaceae, Apocynaceae, Rubiaceae, Papilionaceae, Fabaceae and Moraceae (Borisade, 2019).

There are two prominent seasons in Osun State: the rainy and dry season. The dry season is short, usually lasting four months (October-January). The average rainfall ranges from $1125 \mathrm{~mm}$ in derived savanna to 1475 $\mathrm{mm}$ in the rainforest belt of the state (Osun State website). The mean annual temperature ranges from $39.0^{\circ} \mathrm{C}$ in December to $27.2^{\circ} \mathrm{C}$ in June. The relative humidity in the early morning is generally high, usually over $90 \%$ throughout the year. At midday, it is rather lower, around $80 \%$ in the wet season, as low as $50-60 \%$ in the dry season (Osun State website). The main soils of Osun State are ultisols (low base status forest soil, low available $\mathrm{Ca}, \mathrm{Mg}, \mathrm{K}$ and $\mathrm{Na}$ ), well drained grayish brown to brownish red (Aiboni, 2001). The soils of the area range from moderately to strongly leached and have low to medium humus contents, weakly acidic to neutral surface top soil layers and moderately to strongly acidic sub soils (Smyth \& Montgomery, 1962). The soil textural class across studied sites was sandy clay (Borisade, 2019).

\section{Materials and Methods}

\subsection{Assessment of the regeneration layer of the Study Sites}

The composition of woody species across the riparian forests in southwestern, Nigeria was determined by outlining a line transect of $100 \mathrm{~m}$ on either side of the stream/river (depending on where the regeneration layer is situated) across each study sites, sampling was done via random method in which five (5) $10 \times 10 \mathrm{~m}$ plots were selected at an interval of $15 \mathrm{~m}$ in each site giving a total of 45 plots across study sites (Ifetedo, Ilesha, Osu, Famia, Ibodi, Gbongan, Edunabon, Tonkere, Ipetumodu and assigned as site I-IX, respectively) to assess the regeneration status and structures of common woody species in the riparian forests. Woody species were identified and enumerated to obtain their densities. The identification was done using IFE herbarium as a reference and World Flora Online and Flora of West Tropical Africa (Hutchinson \& Dalziel, 1954-1972). The woody species were termed "common" based on their number of occurrence (frequency) in all the 


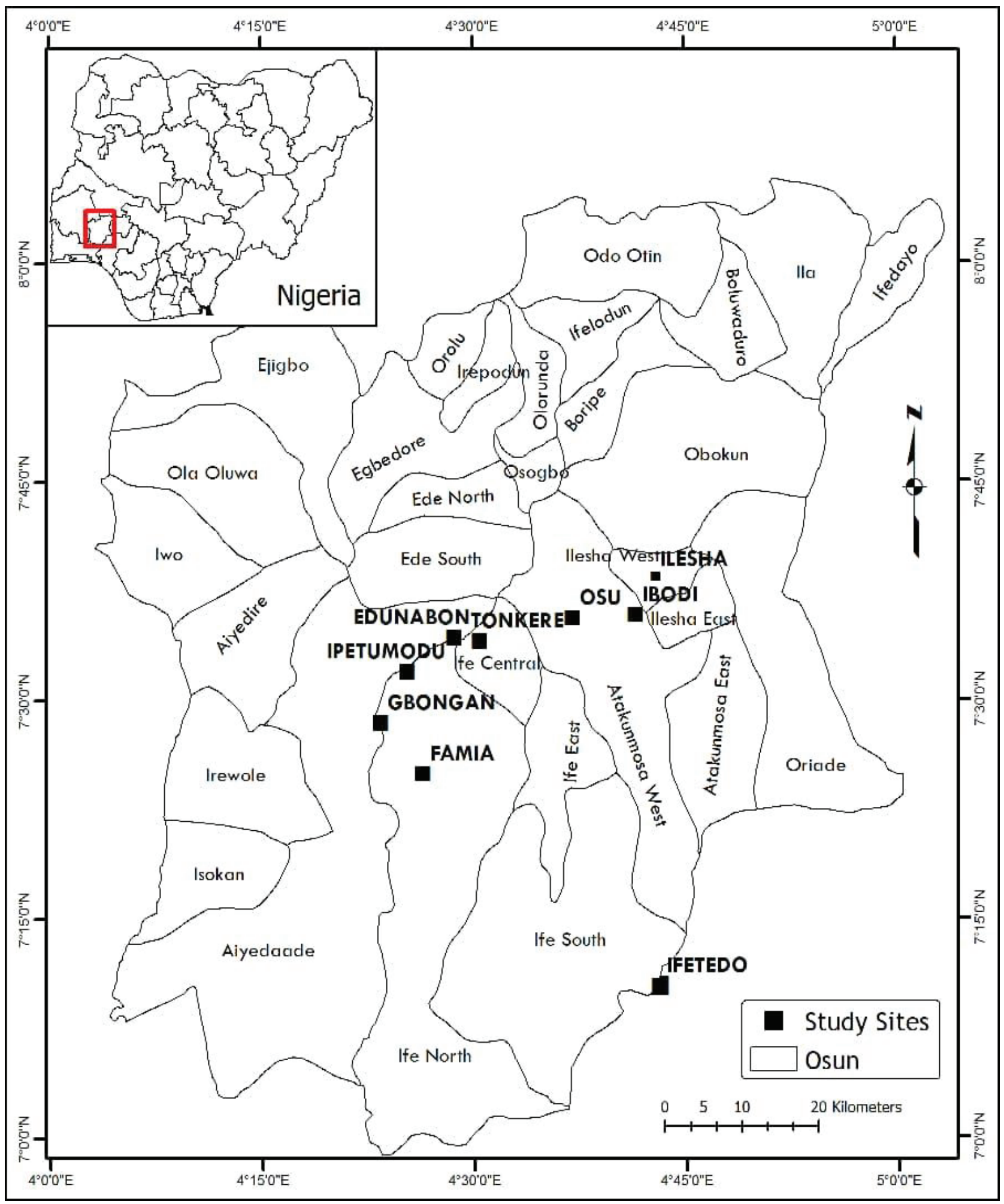

Figure 1. Location of the riparian forests study sites in Osun State in Nigeria 
sites and their important value index of the woody species enumerated in the regeneration layer across study sites.

Woody species were assigned to the following four heights (regeneration) classes; 0-0.5 m (seedlings), 0.5-1 $\mathrm{m}$ (saplings), 1-2 and 2-4 $\mathrm{m}$ (shrubs) and $>4 \mathrm{~m}$ (trees) (Burton et al., 2005).

Regeneration status was determined by analyzing the slope of a linear regression of height classes. This test was performed using PAleontological STatistics (PAST) version 3 software. Height class mid-point was used as the independent variable while the mean number of individuals in each height class was used as dependent variable. The tree/shrub ratio was calculated for each species by dividing the total number of trees by the total number of shrubs. Tree/shrub ratio were used to detect if a given plant population in the regeneration layer were disturbed (Burton et al., 2005; Tsheboeng, 2016). High tree/shrub ratio indicates low level of disturbance while low tree/shrub ratio indicates high level of disturbance (Burton et al., 2005). The One-way analysis of variance (ANOVA) was used to test for the level of significant difference in the mean seedling and sapling densities of common woody species in the regeneration layer across studied sites and the significant means was separated using Fisher's least significant difference (LSD). The tests were performed using IBM SPSS statistics software version 19.0.0.

\section{Results}

The common woody species* found in the regeneration layer across the study sites are five trees (Albizia zygia, Cola acuminata Funtumia elastica Pterocarpus santalinoides. and Newbouldia laevis; four shrubs (Spondias mombin Baphia nitida, Carpolobia lutea and Sphenocentrum jollyanum). There was no significant difference $(\mathrm{p}>0.05)$ in the mean seedling (Table 1) and mean sapling (Table 2) densities of the common woody species across the different riparian forests studied.

The tree/shrub ratio across study sites varied from 0.00 to 1.00. The results showed that Albizia zygia had highest tree/shrub ratio (1.00) in Site IV and Newbouldia laevis in sites II and VII (Table 3), while most other common regenerating woody species have intermediate values across the study sites. There was no tree/shrub ratio $(0.00)$ recorded for Funtumia elastica (in site III and VI), Newbouldia laevis (in site III and IX), Baphia nitida, Pterocarpus santalinoides and Spondias mombin (in site III) and Carpolobia lutea in site IV and VIII (Table 3).

\footnotetext{
${ }^{*}$ nomenclature according to World Flora Online. An Outline Flora of All Known Plants. http://www.worldfloraonline.org.
}

The regression slope showed on-going regeneration (mostly, weak on-going regeneration) of the common woody species in all the riparian sites (Table 4). The regression analysis indicated negative slope for common woody plant species in the regeneration layer and was significant across study sites except in some sites where species showed no level ( $\mathrm{p}>0.05)$ of significance e.g Albizia zygia (Site I, II, III, IV, VI and VIII), Pterocarpus santalinoides (Site I, III, IV, V and VII), Spondias mombin (Site I, III, IV, VI and VIII) (Table 4). The regeneration structure elaborated on the basis of height classes showed a similar pattern of a reverse J-shaped of the constituent woody species across the different study sites, with more individuals distributed at the height classes $0-0.5 \mathrm{~m}$ and 0.5-1 m (Fig. 2a-i).

\section{Discussion}

The common woody species recorded across the sites showed variation in regeneration dynamics as evident in their tree/shrub ratio. The intermediate values of tree/shrub ratio shown by the common woody species encountered in the regeneration layer indicated more individuals of shrub size than tree and it emphasized the fact that the level of disturbance ongoing was moderate across study sites as it has been explained that high tree/shrub ratios implies that the disturbance level is low by reflecting more individuals of tree size than of shrubs in the regeneration layer of forest ecosystems (Gurmessa et al., 2012; Tsheboeng, 2016).

The lack of significant differences observed in the seedling and sapling densities of the common woody species across the studied riparian forest sites might indicate similarities in the seed dispersal efficiency, germination rates and almost same level of anthropogenic disturbances for these species across study sites. Environmental factors, which favour emergence of seedlings and sapling in the regeneration layer were possibly not pronounced from one site to the other. It has been explained that environmental factors which impede germination and survival of seeds to maturity would have to be pronounced to ascertain if the regeneration status of plant species will differ from others within a community (Barnes, 2001; Burton et al., 2005; Tsheboeng, 2016).

The reverse J-shaped obtained in this study implies that the regeneration structures of the common woody species are currently on-going as most individuals were distributed in the lower size-classes (0-0.5 and 0.5-1 m). Mwavu \& Witkowski (2009) highlighted similar observation on seedling regeneration of semi-deciduous African tropical rainforest in Uganda. Sambare et al. (2011) observed that the height class distribution of trees in all riparian forests showed a reverse "J" shaped curve except riparian forest of stream indicating vegetation dominated by juvenile 


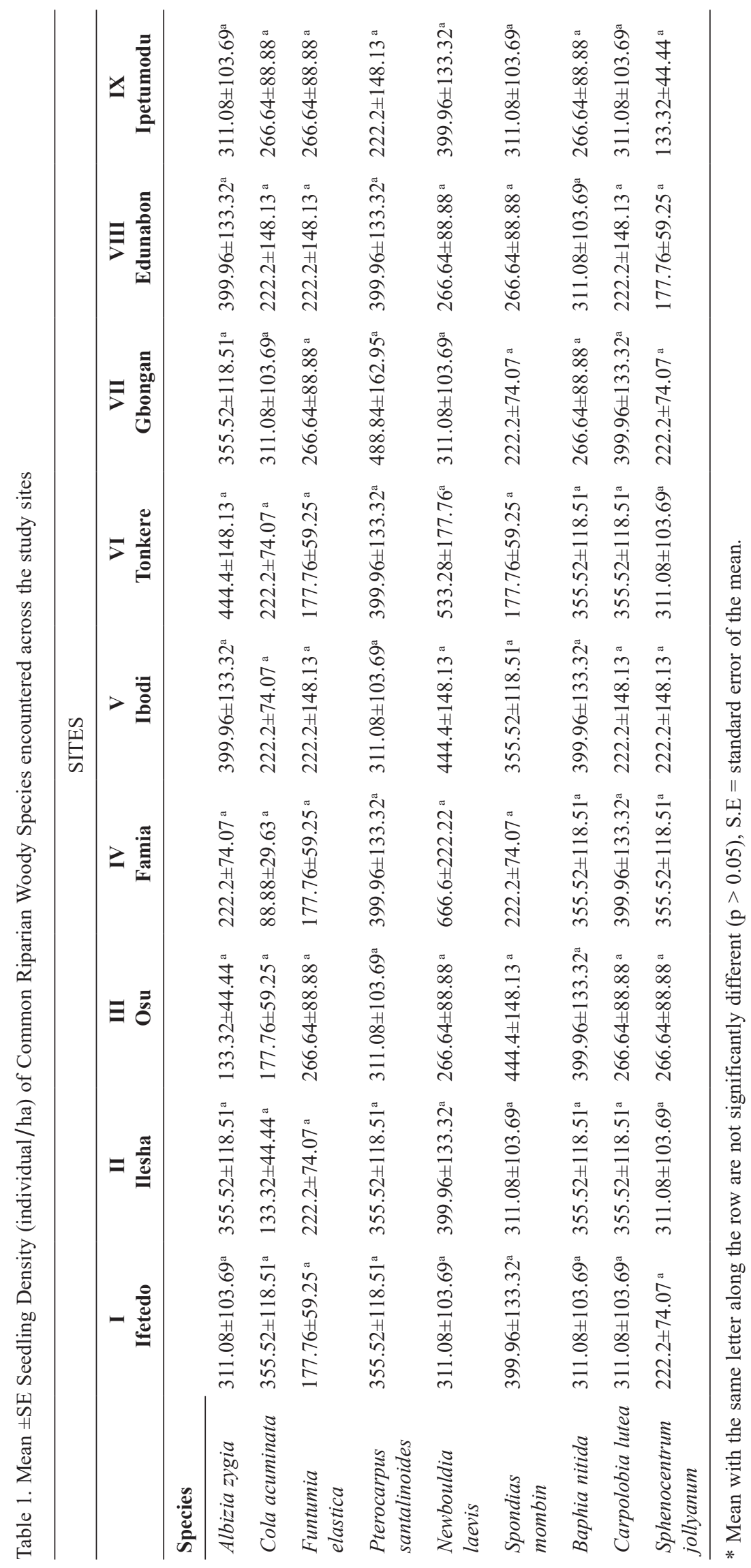




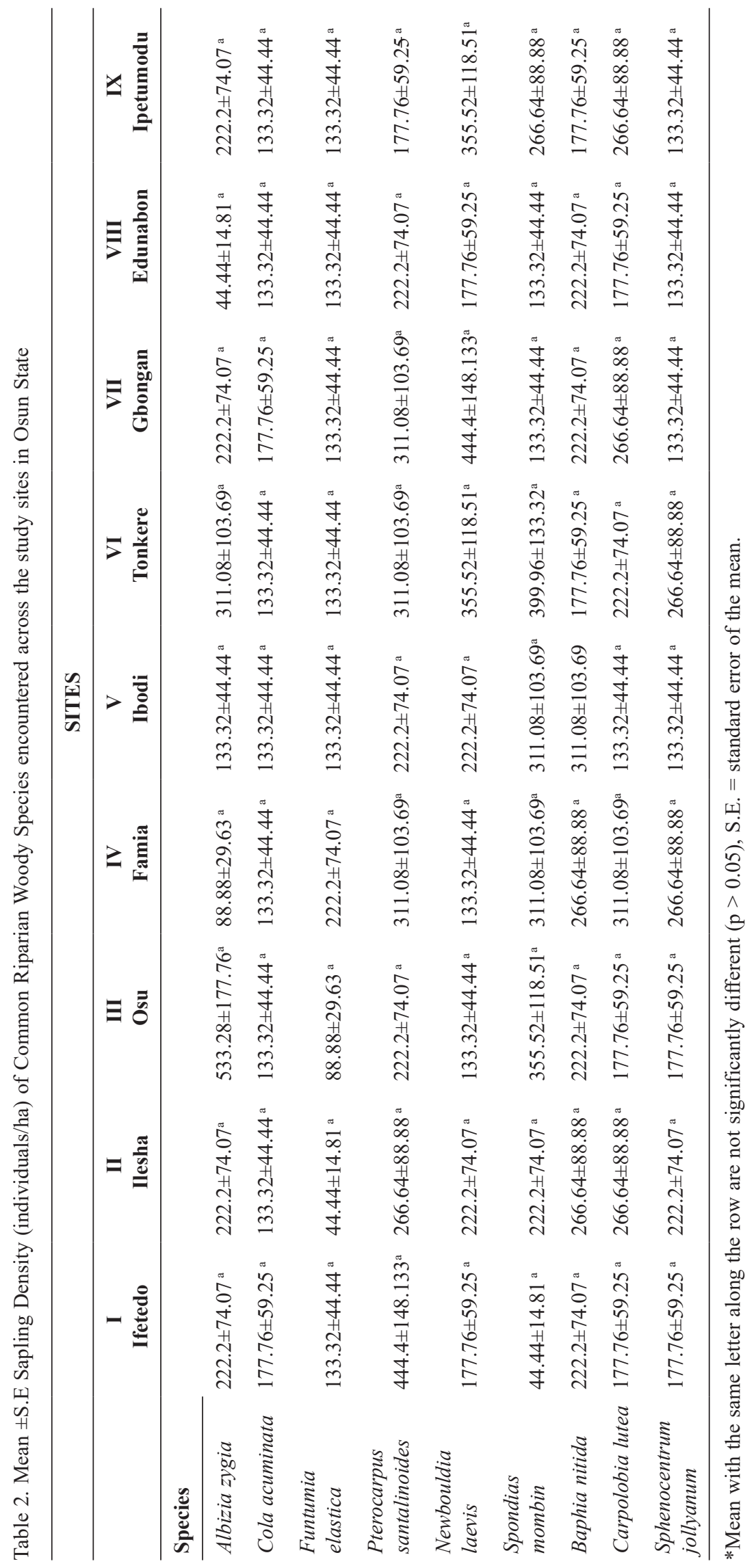




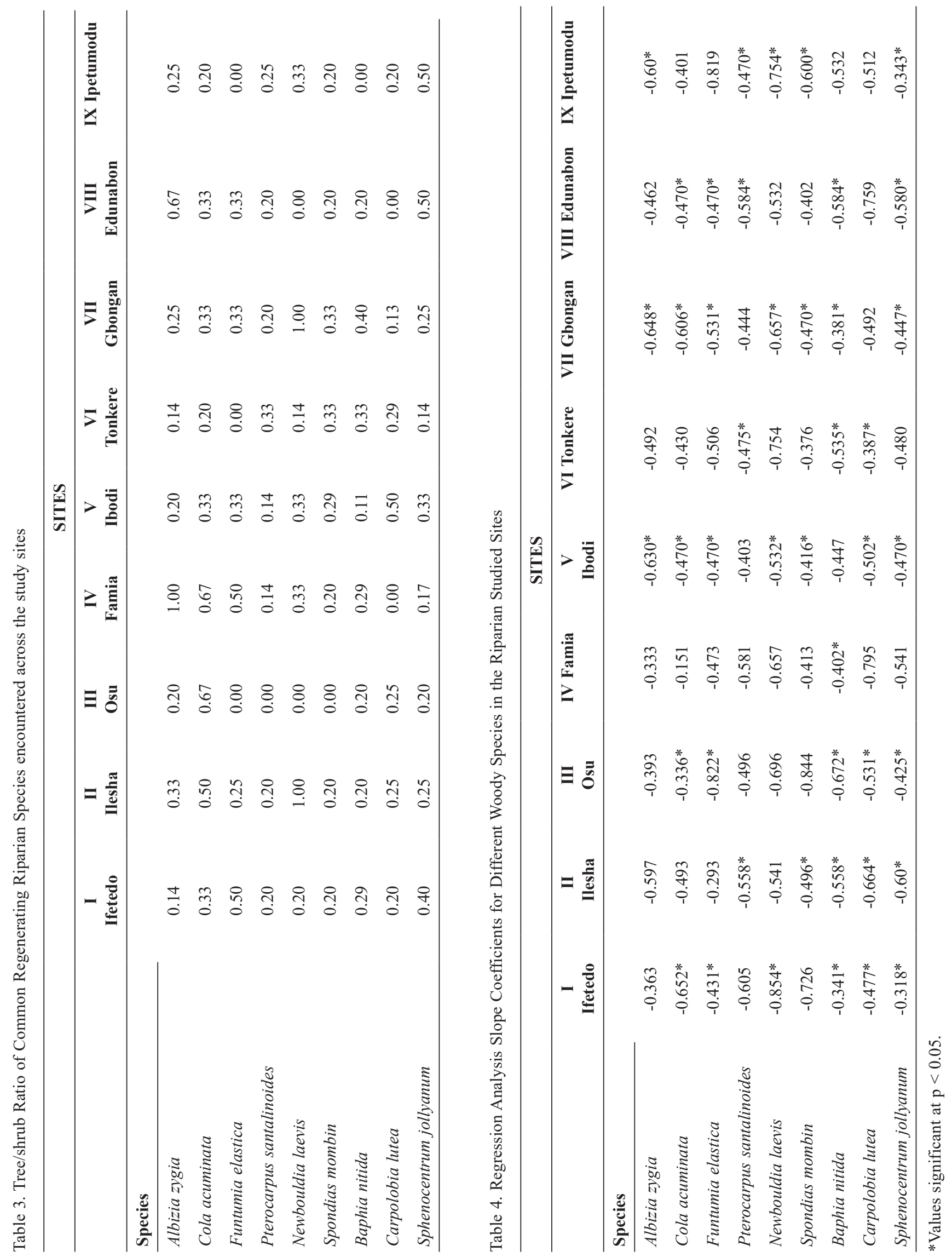



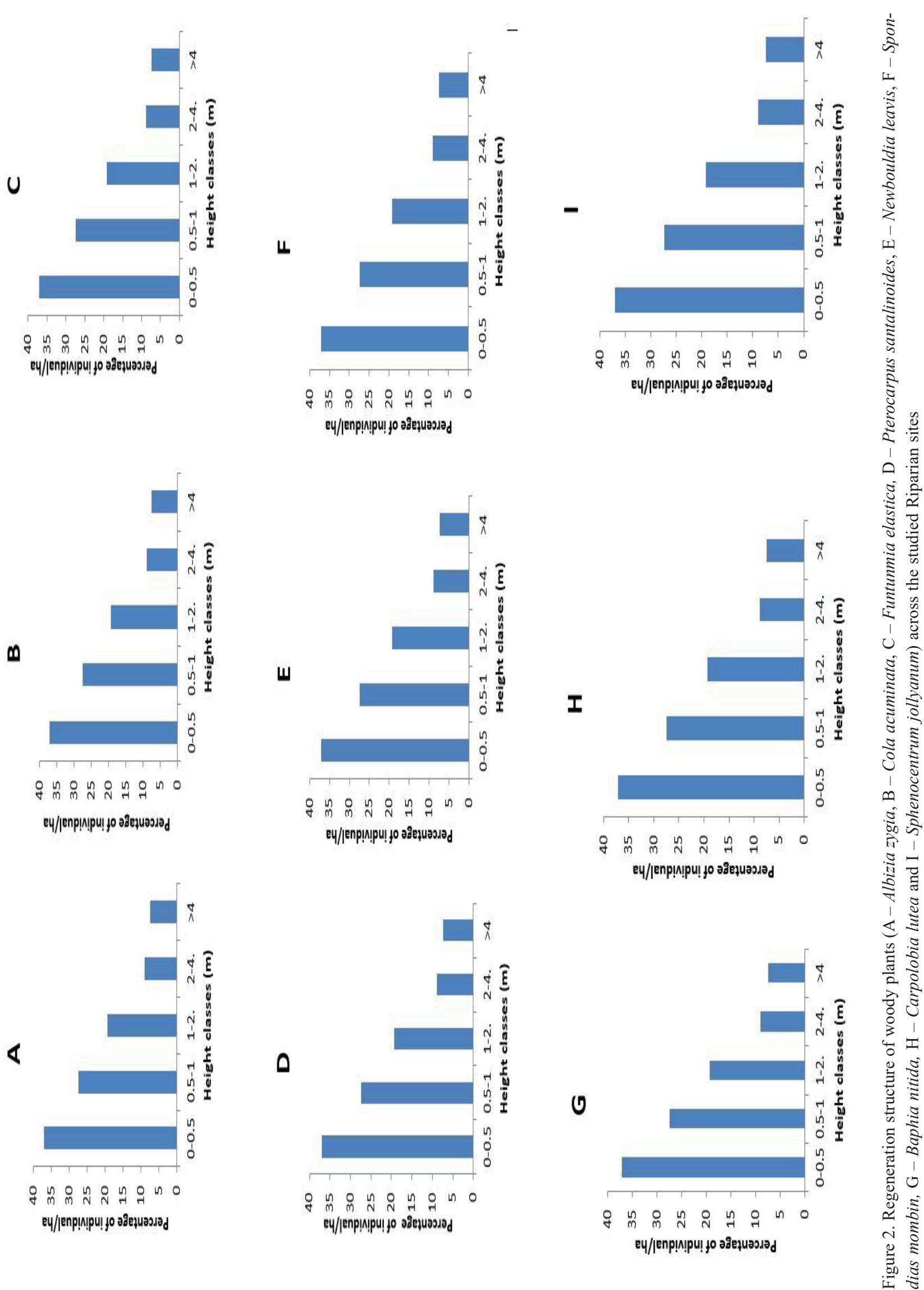
individuals along four watercourses types in their study in Burkina Faso. Tsheboeng (2016) also reported that Philenoptera violacea species showed a reverse J-shaped among the common woody species studied across the riparian forests sites in Botswana. The weak negative regression slope across riparian sites in this study further explained the regeneration pattern of common woody species that have been influenced by the loss of individual of tree size than shrubs, saplings and seedling stages. Anthropogenic activities such as mining, farming, logging and herbivory have probably influenced the regeneration pattern of the common woody species encountered across the riparian forest sites.

It has been hypothesized that environmental factors that generally influenced regeneration and population structure in forests include fire, herbivory (grazing), flooding, pathogens, competition and light regime (Chow, 2012; Oliveira et al., 2014; Tsheboeng, 2016), habitat preferences and seed predators (Mwavu \& Witkowski, 2009). Anthropogenic factors have been observed to affect the regeneration and the population structure of riparian woody species of Osun State, Nigeria. These include activities such as land clearing for agriculture, timber harvesting and human settlements (Maitima et al., 2009; Borisade et al., 2021) as applicable in this study. Other anthropogenic activities, which have been reported to affect the regeneration of riparian woody species include dam construction in catchment areas, urbanization of catchment areas, changes to hydrology and climate (Parolin \& Wittmann, 2010) though not applicable in our study. Some of the species observed to be common in the regeneration layer of the riparian forests studied are typical of the West African gallery forest and their status like most riparian forests in Africa have been greatly modified by anthropogenic activities (Mining of Gold, Grazing of livestock, Agriculture, Urbanization, Fishing), ubiquitous in the region.

The tree/shrub ratio of common woody species in the regeneration layer indicated moderate disturbances and invariably, was responsible for no significant level in the regression slope analysis of species across some of the study sites, hence possible recovery from disturbances. Sustainability of these woody species in the regeneration layer requires proper management and conservation of these species for survival by preventing human interferences (agriculture, grazing, fishing, mining of gold and conversion to other land uses) ubiquitous in the region especially by indigenes whose means of livelihood depends on the resources offered by this eco-zone.

\section{Conclusions}

The regression slope showed on-going regeneration (mostly weak) of the common riparian woody species and the regeneration structures indicated reverse J-shaped and have been greatly modified by prevalent anthropogenic activities in the study area. The pattern of regeneration status observed in the seedlings and saplings occurrence in the regeneration layer was due to the similar environmental factors that occurred from one site to the other. The intermediate values of tree/shrub ratio shown by the common woody species encountered in the regeneration layer indicated more individuals of shrub than tree size and it emphasizes the fact that the level of disturbance ongoing was moderate and possibly that the sites are recovering from disturbances.

\section{References}

Adel M.N., Pourbabaei H., Saleh A., Alavi S.J. \& Dey D.C., 2018, Structure, composition and regeneration of riparian forest along an altitudinal gradient in northern Iran. Folia Geobot. 53: 63-75.

Aiboni V.U., 2001, Characterization of some soils under different landuse along a toposequence in Ibadan, Nigeria. Asset Series A.1: 51-61.

Baker T.T., 2002, What is a riparian area? Cooperative Extension Service Animal Resources Department. New Mexico State University. Las Cruces, NM. http://cahe. nmsu.edu/riparian/WHTRIPAREA

Barnes M.E., 2001, Seed predation, germination and seedling establishment of Acacia erioloba in northern Botswana. J. Arid. Environ. 49: 541-554.

Borisade T.V., 2019, Assessment of plant communities, diversity and soil properties of riparian forests in Osun State, Nigeria. A Ph.D Thesis submitted to the Department of Botany, Obafemi Awolowo University, Ile-Ife, Nigeria.

Burton M.L., Samuelson L.J. \& Pan S., 2005, Riparian woody plant diversity and forest structure along an urban-rural gradient. Urban Ecosystems 8: 93-106.

Borisade T.V., Odiwe A.I., Akinwumiju A.S., Uwalaka N.O \& Orimoogunje, O.I., 2021, Assesing the impacts of land use on riparian vegetation dynamics in Osun State, Nigeria. Trees, Forests and People 5 (2021)100099.

Charter J.R., 1969, Map of Ecological Zones of Nigerian Vegetation. Federal Department of Forestry, Ibadan, Nigeria, 21 pp.

Chow L., 2012, A literature review of riparian buffer widths for sediments, nutrients and large woody debris. B.Sc. Thesis. University of British Colombia, Vancouver, British Colombia.

DSE, 2010, Flora and Fauna Guarantee Act Listed Taxa, Communities and Potentially Threatening Processes Victorian Department of Sustainability and Environment, Melbourne. http://www.dpi.vic.gov.au/DSE/ nrenpa.ns f/LinkView/ [18 July 2016]. 
Gurmessa F., Soromessa T. \& Kelbessa E., 2012, Structure and regeneration status of Komto Afromontane moist forest, East Wollega Zone, west Ethiopia. Journal of Forestry Research 23: 205-216.

Hall J.B., 1969, The vegetable of Ile-Ife. University of the Ife Herbarium Bulletin. Bulletin of Transilvania 2(51): 13-18.

Hutchinson J. \& Dalziel J.M., 1954-1972, Flora of West Tropical Africa (Revised editions). Crown Agents, London.

Keay R.W.J., 1959, An outline of Nigerian vegetation. 3rd edition. Federal Ministry of Information, Lagos (1960). An example of the northern Guinea zone vegetation in Nigeria. Information Bulletin Department of Forestry Research Nigeria 1: 1-3.

Magdaleno F., Martínez R. \& Roch V., 2010, Índice RFV parala valoración del estado del bosque de ribera. Ingeniería Civil 157: 85-96.

Maitima J.M., Mugatha S.M., Reid R.S., Gachimbi L.N., Majule A., Lyaruu H., Pomery D., Mathai S. \& Mugisha S., 2009, The linkages between land use change, land degradation and biodiversity across east Africa. African Journal of Environmental Science and Technology $3:$ 310-325.

Mwavu E.N. \& Witkowski E.T.F., 2009, Seedling regeneration, environment and management in a semi-deciduous African tropical rain forest. J. Veg. Sci. 20: 791804.

Oliveira M.T., Damasceno-Junior G.A, Pott A., Paranhos Filho A.C, Suarez Y.R \& Parolin P., 2014, Regenera- tion of riparian forests of the Brazilian Pantanal under flood and fire influence. Forest Ecology and Management 331: 256-263.

Parolin P. \& Wittmann F., 2010, Struggle in the flood: The responses to flooding stress in four tropical floodplain systems. AoB Plants. DOI:10.1093/aobpla/plq003

Pettit N.E. \& Naiman R.J., 2007, Fire in the Riparian Zone: Characteristics and Ecological Consequences. Ecosystems 10: 673. DOI:10.1007/s10021-007-9048-5

Robertson A.I. \& Rowling R. W., 2000, Effect of livestock on riparian zone vegetation in an Australian dryland river. Regulated Rivers: Research and Management 16: 527-541.

Sambare O., Bognounou F., Wittig R. \& Thiombiano A., 2011, Woody species composition, diversity and structure of riparian forests of four watercourses types in Burkina Faso. J. Forestry Res. 22: 145-158.

Smyth A.J \& Montogemery F.R., 1962, Soil and Land Use in Central Western Nigeria. The Government of Western, Ibadan, p. 143-168.

Tsheboeng G., 2016, Population structure, species composition and distribution of riparian woody plant communities in the Okavango Delta, Botswana. Ph.D. thesis. University of Botswana, Botswana.

White F., 1983, The vegetation of Africa-A descriptive memoir to accompany the UNESCO/AET FAT/UNSO vegetation map of Africa. UNESCO, Paris, $365 \mathrm{pp}$.

World Flora Online. An Outline Flora of All Known Plants. http://www.worldfloraonline.org. 